\title{
Policy Forum: Macroeconomic Policies after the Global Financial Crisis
}

\section{Macroeconomic Policies in a Low Interest Rate Environment: Back to Keynes?}

Efrem Castelnuovo, Guay Lim and Giovanni Pellegrino*

* Castelnuovo: Department of Economics and Melbourne Institute of Applied Economic and Social Research, The University of Melbourne, Victoria 3010 Australia; Lim and Pellegrino: Melbourne Institute of Applied Economic and Social Research, The University of Melbourne, Victoria 3010 Australia. Corresponding author: Castelnuovo, email <efrem.castelnuovo@unimelb.edu.au>. Financial support from the Australian Research Council via the Discovery Grant DP160102281 is gratefully acknowledged.

\begin{abstract}
This article discusses macroeconomic policies in a low interest rate environment, the central theme of the 2017 edition of the Melbourne Institute Macroeconomic Policy Meeting. After reviewing possible causes of the decline in interest rates observed since the 1990s, we present and discuss some of the challenges that monetary and fiscal policy face in a 'new normal' environment characterised by a real natural interest rate close to zero. Proposals by leading researchers on how to operate in such an environment are presented and discussed. We conclude by outlining some research questions that are highly relevant from a policy perspective.
\end{abstract}

This is the author manuscript accepted for publication and has undergone full peer review but has not been through the copyediting, typesetting, pagination and proofreading process, which may lead to differences between this version and the Version of Record. Please cite this article as doi: $10.1111 / 1467-8462.12258$ 


\section{Introduction}

Following the global financial crisis (GFC), there has been a lot of discussion about how to conduct macroeconomic policies in a 'new normal' environment featuring a lower natural real interest rate (Williams 2017). This natural interest rate, which was first conceptualised by the Swedish economist Knut Wicksell (1898), often formalised as ' $r$ '', is the real shortterm interest rate consistent with output being at its potential and the inflation rate at its target. Not surprisingly, the natural real interest rate is of paramount importance for policymakers, especially as a reference measure. The stance of monetary policy is expansionary (contractionary) when the real policy interest rate is below (above) the natural rate. Hence, knowing the value of the real natural interest rate (or, at least, having an estimate of its value) is crucial for designing policy actions.

During the GFC, the Reserve Bank of Australia (RBA) brought the cash rate down from a high of 7.25 per cent (August 2008) to a low of 3.00 per cent (April 2009). This was one of the factors that helped Australia avoid a severe recession (see Lim et al. 2009 for a review). Since then, the RBA has engineered another big drop in the cash rate from 4.75 per cent in November 2010 over a period of more than 6 years to 1.5 per cent in August 2016, and it has been held at that level since. In spite of this accommodative monetary policy, Australia has not escaped concerns that the economy could be operating at a 'new normal' with average growth post-GFC much lower than average growth pre-GFC, as clearly documented by Figure 1.

Although the Australian policy cash rate is not at the zero lower bound (ZLB), the cash rate is effectively at a lower bound because further cuts are unlikely out of concern that lower mortgage rates may fuel a house price bubble. The need to understand the Australian 'natural rate of interest' has also been highlighted recently. The minutes of the July 2017 meeting of the Board of the RBA (RBA 2017) comment on research that estimates the Australian 'neutral nominal interest rate' to be around 3.5 per cent, and the natural real rate around 1 per cent (see McCririck and Rees 2017). 
Figure 1 Evolution of the Growth Rate of Real GDP and the Cash Rate in Australia

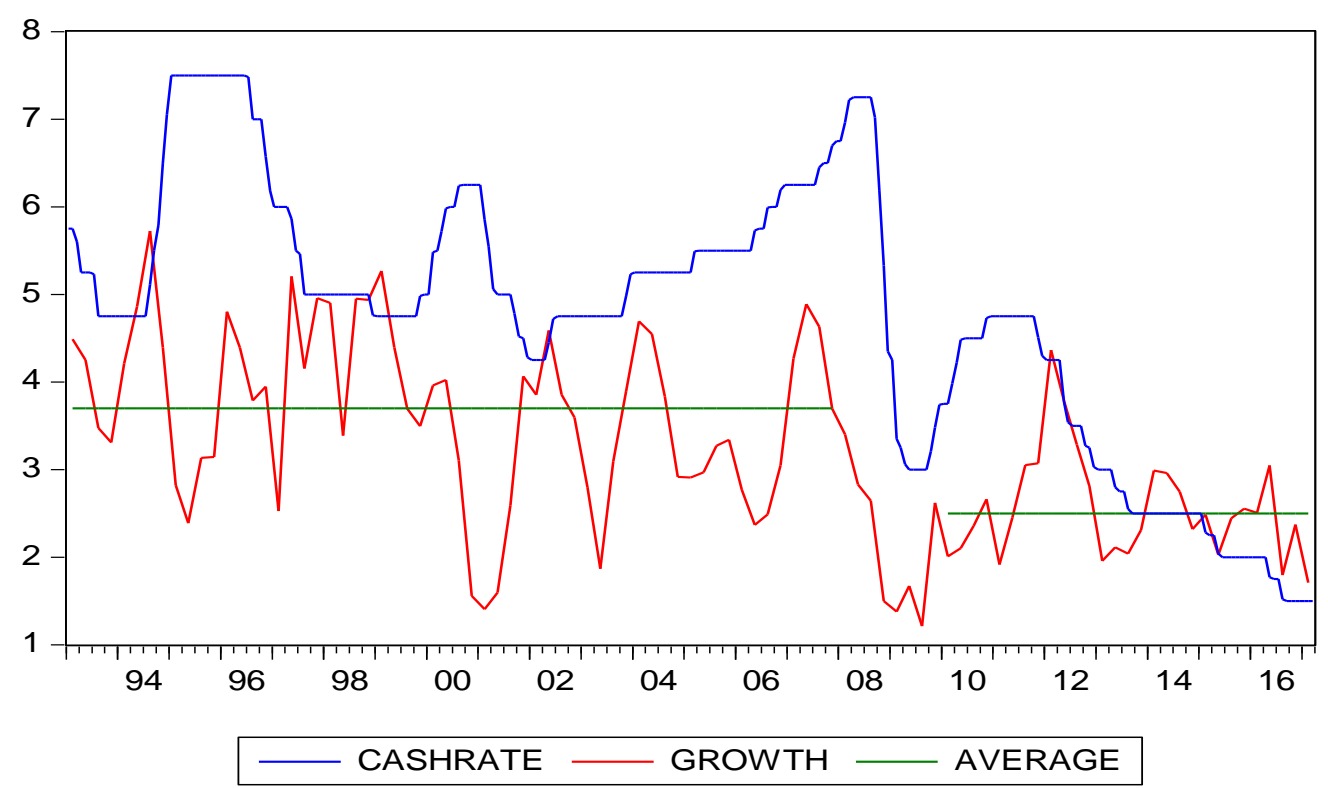

This article is a summary of the issues discussed around the main theme of the MI Macro Policy Meeting held on 5-6 October 2017, namely the decline in $r^{*}$ in the United States and around the world and the consequences for macroeconomic policies. ${ }^{1}$ The Meeting featured a number of high quality scientific papers as well as a panel discussion facilitated by Bruce Preston (University of Melbourne) with panellists Guy Debelle (RBA), Anella Munro (Reserve Bank of New Zealand) and Nigel Ray (Australian Treasury). Discussions, questions and answers at the Meeting offered insights and assessments of macroeconomic policies conducted before, during and after the GFC in Australia and around the world. ${ }^{2}$ This article relates some of the evidence presented at the Meeting to the extant literature.

To begin, as the definition suggests, the natural rate is a latent (unobservable) variable, which needs to be estimated. At the Melbourne Institute workshop, Marc Giannoni (Senior Vice President and Director of Research, Federal Reserve Bank of Dallas) presented a paper (Del Negro et al. 2017) that provided estimates of the natural real rate in the United States. The authors apply state-of-the-art econometrics to estimate a reduced form Vector AutoRegression (VAR) model with shifting endpoints and a medium-scale Dynamic Stochastic General Equilibrium (DSGE) framework. Both models are estimated using macroeconomic aggregates like inflation and output growth as well as financial indicators like the convenience yield (the difference between the yield of low-quality assets like those classified as BAA by Moody's and the yield of equal-maturity, safe assets like government bonds). Del Negro et al. (2017) find that the natural real rate was relatively stable between the early 1960s to the 1990s, but it has since steadily declined. Figure 2 depicts their 
baseline estimates, which suggest that the natural real interest rate is likely to have fallen from about 2.5 per cent in the late 1990 s to the current 1.5 per cent.

Figure 2 Evolution of the Natural Real Interest Rate in the United States as Estimated by a Flexible Reduced-Form VAR Model and by a State-of-the-Art DSGE Framework

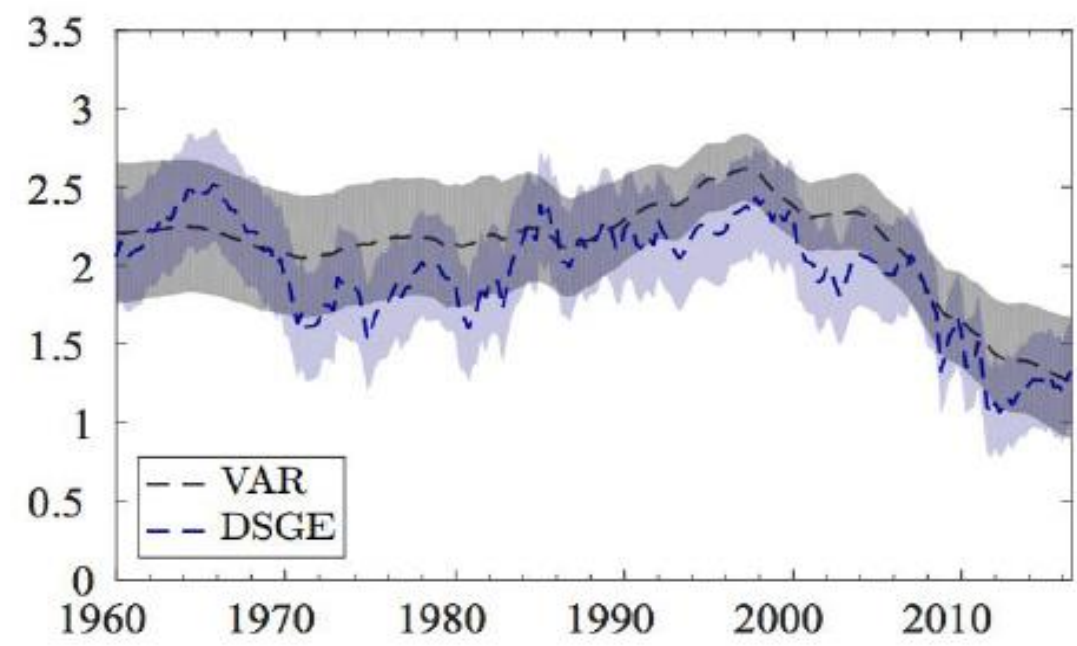

Source: Del Negro et al. (2017).

The remaining sections of this article link the evidence outlined above to the extant literature, which has proposed interpretations for this fact and discussed policy implications. Section 2 discusses various drivers of the fall in the real natural rate in the United States and other countries. Section 3 highlights some challenges policy-makers have to face in a low interest rate world, with emphasis on monetary and fiscal policies. Section 4 concludes by pointing out a few avenues for future research.

\section{Low Real Natural Interest Rate: Drivers}

The recent literature has proposed a number of possible explanations for the fall in the real natural interest rate. Not surprisingly, they are related to the drivers of savings and investment; put simply, low interest rates reflect a situation when there is too much savings and too little investment.

\subsection{Demographic Transition}

Carvalho, Ferrero and Nechio (2016) note that demographic transition can affect $r^{*}$ via three channels. One channel is the increase in life expectancy, which leads economic agents to increase their current desired savings in the face of longer periods of retirement. This channel works to lower the natural real interest rate. The other two channels are associated with a slowdown in population growth, which in turn implies a reduction in the size of the working population. On the one hand, capital-per-worker rises, reducing the marginal 
product for capital and putting downward pressure on the real natural rate. On the other hand, the fraction of retirees to workers (the 'dependency ratio') increases, lowering the aggregate savings rate (retirees save less than workers) and putting upward pressure on the real natural rate. Working with a calibrated life-cycle model with demographic features, Carvalho, Ferrero and Nechio (2016) replicate the estimated fall in the real natural rate between 1990 and 2014 (see also Gagnon, Johannsen and López-Salido 2016 for a similar conclusion on the role of demographics).

\subsection{Uncertainty and Convenience Yields}

Another factor leading to an increase in desired savings is uncertainty (Bloom 2009), although in general equilibrium an increase in desired savings could be accompanied by a decrease in realised savings (Basu and Bundick 2017). Related to this, Del Negro et al. (2017) focus on the search for safety and liquidity by investors and find that the key driver of the decline of the natural rate in the United States is the rise in the convenience yield (driven by an increasing appetite for safe assets like US bonds). Their conclusion is consistent with the evidence that yields of securities that are less liquid and less safe than treasury bonds, like corporate bonds, have declined by much less. Del Negro et al.'s (2017) evidence calls for an understanding of forces behind the movements in the convenience yield and, more generally, in credit spreads. Research by Caldara et al. (2016) shows that uncertainty shocks can explain a non-negligible fraction of the volatility of credit spreads since World War II while Caggiano et al. (2017) quantify the evolution of the finance-uncertainty multiplier and find the recessionary effects of financial uncertainty to be particularly strong during the GFC. Importantly, they show that financial frictions are crucial to explain this result; that is, it is the increase in credit spreads after an uncertainty shock that cause a recession. Absent financial frictions, the real effects of uncertainty shocks would have been negligible even in the 2007-2009 period. $^{3}$

\subsection{Secular Stagnation and Productivity}

Arguments from the investment side explain low interest rates are more varied. For example, Summers (2014) suggests secular stagnation as an explanation, arguing that weak aggregate demand, especially a low demand for productive investment, would shift the equilibrium value of the real natural interest rate down. Looking at investment also leads naturally to considerations of production and technical change. Laubach and Williams (2016) identify the fall in the growth rate of potential output as the main driver of the decline of the low natural interest rate. This follows from their consideration of the Euler equation for consumption, which maps a relationship between steady-state growth and the real one-period interest rate. However, Hamilton et al. (2016) challenge this proposition with a cross-country data analysis covering a long sample starting in the 1800 s. They find only a weak link between the real natural interest rate and output growth. Another possible 
explanation is that investment-specific technical change has led to a decline in the price of capital resulting in excess savings and a reduction in the real natural interest rate (Eichengreen 2015). Tangentially, Gordon's (2012) study on the rise and fall of growth in the United States leads to pessimism that innovations will lead to a surge in productivity and increase investment. In contrast to techno-optimists, Gordon argues that incremental improvements' and 'headwinds' (structural changes associated with demography, education, inequality, globalisation, energy/environment and the overhang of consumer and government debt) will remain a drag on investment and output for some considerable time.

\subsection{Savings Glut and International Linkages}

Bernanke (2005) proposes a 'savings glut' explanation, namely that low interest rates reflect the global shortage of safe assets. An international perspective underpins also Holston, Laubach and Williams' (2017) study, which estimates the low frequency component of the real interest rate for the United States, Canada, the Euro Area and the United Kingdom. They find that, since the late 1990s, estimates of the underlying rate have fallen. Given the high degree of synchronisation displayed by the estimates of the real natural interest rate across these four countries, they too speculate that global factors may be at work. Fries et al. (2017) estimate the evolution of $r *$ for Germany, France, Spain and Italy and find that while the degree of synchronisation is lower for these countries, nonetheless real interest rate gaps have converged to zero in all four economies since 2014. Evidence on a generalised fall in real natural interest rate is also provided by Rachel and Smith (2017). This generalised fall in the real rates may have been driven by global factors. Miranda-Agrippino and Rey (2015) identify a global factor that affects movements in asset prices across countries. Another global factor affecting yields at an international level is global uncertainty. See Davis (2016), Carriero, Clark and Marcellino (2017), Caggiano and Castelnuovo (2017), Mumtaz and Theodoridis (2017) and Kang, Ratti and Vespignani (2016); for related evidence on uncertainty spillovers, see Colombo $(2013)$, Bloom $(2014,2017)$ and Caggiano, Castelnuovo and Figueres (2017a).

\section{Macroeconomic Policies when the Real Natural Interest Rate is Low}

Low real natural interest rates have implications for monetary and fiscal policy. As expected, this is likely to occur when the ZLB is binding. Under these circumstances, there is growing recognition that macroeconomic policies have to take into account increased macroeconomic uncertainty, stronger effects of recessionary shocks and the consequences of hysteresis. 


\subsection{Uncertainty, Recessionary Shocks and Hysteresis}

Uncertainty can be generated by a variety of sources. It can be due to future policy moves (Baker, Davis and Bloom 2016; Istrefi and Mouabbi 2017; Dalhaus and Sekhposyan 2017), future realisations of the stock market (Ludvigson, Mah and $\mathrm{Ng} 2017$ ) as well as to future realisations of fundamentals such as technology or households' preferences. The sharp rise in uncertainty when the policy rate hit ZLB during the 2007-2009 great recession is shown quite spectacularly in the plots of the US federal funds rate and the VXO (a measure of implied volatility often used as an empirical proxy for macroeconomic uncertainty) in Figure 3.

Figure 3 VXO and Federal Funds Rate

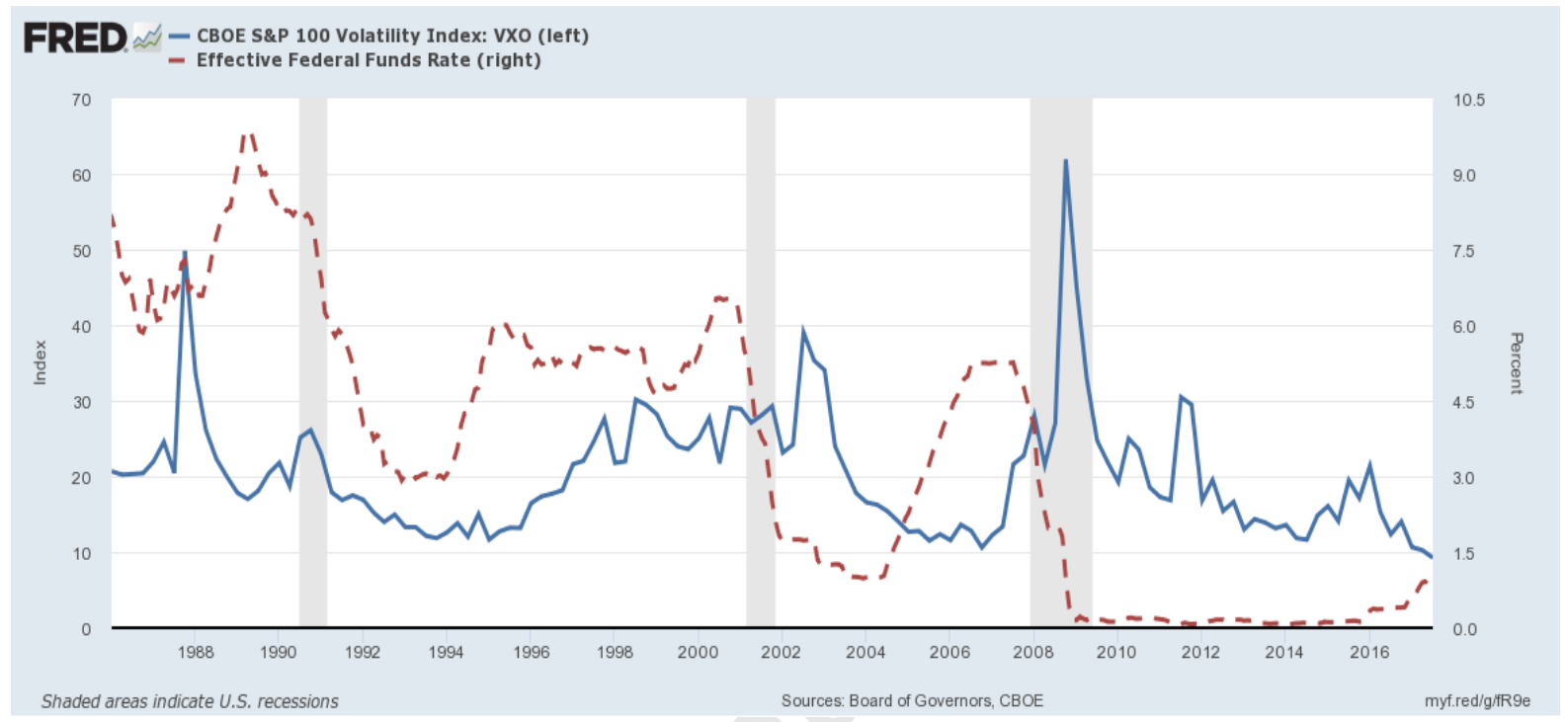

Source: Federal Reserve Bank of St. Louis' website.

Spikes in uncertainty have been documented to negatively affect the business cycle (Bloom 2009; Jurado, Ludvigson and Ng 2015; Bloom et al. 2016; Ludvigson, Mah and Ng 2017), especially when the economy is already experiencing slack (Caggiano, Castelnuovo and Groshenny 2014; Nodari 2014; Caggiano, Castelnuovo and Pellegrino 2017; Caggiano, Castelnuovo, and Figueres (2017b); Castelnuovo and Tran 2017) or is the zero lower bound (Caggiano, Castelnuovo and Pellegrino 2017). There is now a body of evidence to show that the effects of recessionary shocks are in general stronger than otherwise when the ZLB is binding. ${ }^{4}$

Recent research also shows that, in the presence of uncertainty, policy moves have to be particularly aggressive to be effective (for a survey, see Castelnuovo, Lim, and Pellegrino 2017). Pellegrino $(2017,2018)$ finds that monetary policy shocks in the United States and Europe are less effective in the presence of high uncertainty (for further evidence, see 
Aastveit, Natvik and Sola 2017; Eickmeier, Metiu and Prieto 2016).This may be due to a 'wait-and-see' type of optimal behaviour by households and firms, which prefer to postpone the purchase of durable consumption and productive capital to periods when uncertainty is lower. In this scenario, changes in relative prices are less effective in the presence of uncertainty. Castelnuovo and Pellegrino (2017) show that monetary policy shocks in the presence of high uncertainty imply a weaker response of real activity and a stronger response of prices, a prediction in line with a steeper slope of the new-Keynesian Phillips curve in uncertain times due to more flexible prices. For a study of fiscal policy, see Ricco, Callegari and Cimadomo (2016), who employed a nonlinear VAR to show that fiscal policy shocks are less effective in the presence of uncertainty. The upshot of these empirical contributions is that they suggest strong interventions by monetary and fiscal policy-makers are needed for these policies to have an impact on the business cycle, a message corroborated also by further evidence on weaker effects of systematic monetary policy in recessions (Caggiano, Castelnuovo and Nodari 2017).This evidence offers support to the interventionist position recently advocated by Blanchard and Summers (2017).

Perhaps the most compelling reason for active macro policies is hysteresis-the phenomena when shocks that affect business cycle fluctuations also affect the trend levels. Figure 4, reproduced from Blanchard (2017), shows the evolution of the log-real GDP in the United States and the Euro Area. The downward shift of the level of real GDP during the GFC is clear, but what is also clear is that almost a decade after the GFC, there are still no signs of reversals to the previous trend. According to Summers (2014), this is one of the most spectacular pieces of evidence in favour of hysteresis. In the presence of such evidence of hysteresis, it has been suggested that, after a crisis like that in 2007-2009, one should engineer expansionary policies to allow output to exceed its potential to enable workers who have left the labour force during the last ten years to be re-integrated back into the economic system (Blanchard 2017). 


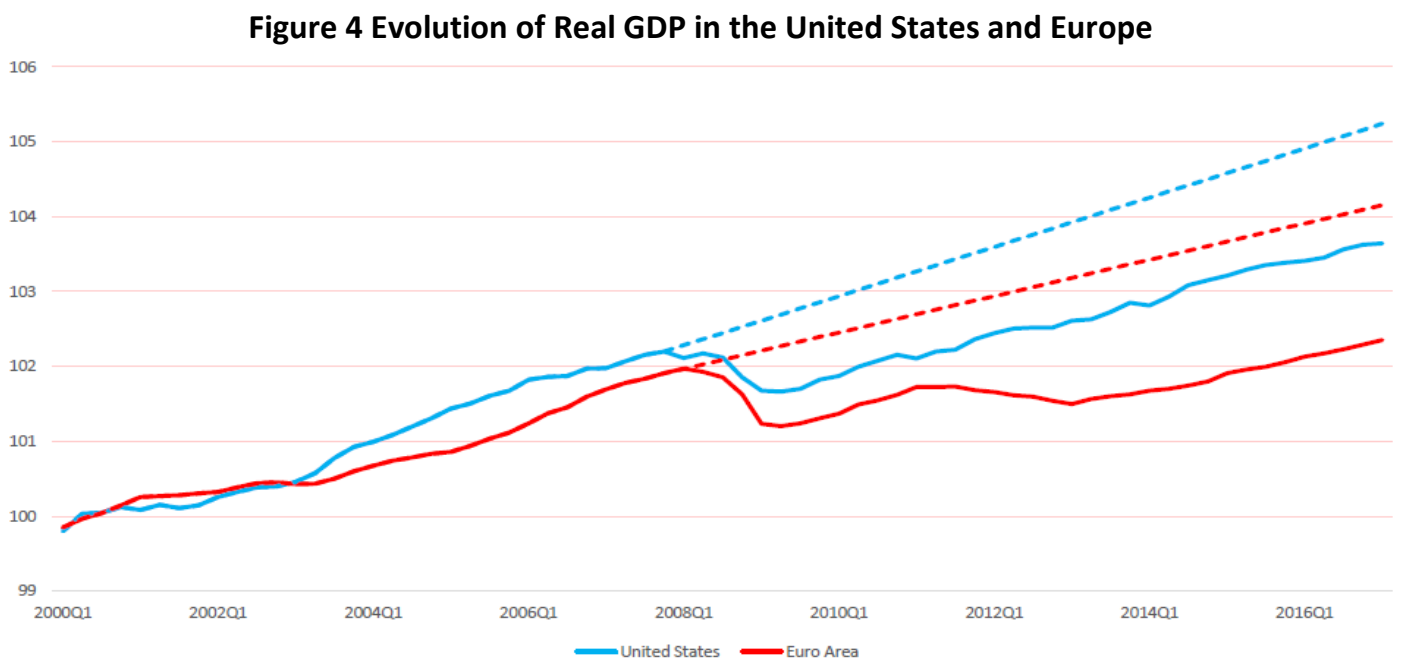

Source: Blanchard (2017).

\subsection{Monetary Policy: New Instruments and New Targets}

\subsubsection{Unconventional Monetary Policy}

During and after the GFC, central banks resorted to implementing unconventional monetary policies to overcome their inability to lower rates further. Although these unconventional policies are not considered to be perfect substitutes for conventional policy moves (Yellen 2016), there is some evidence that they can be effective. This has prompted Bernanke (2017) to propose the use of these tools as supplements to standard policy rate cuts. In particular, he focuses on forward guidance and quantitative easing.

Forward guidance is the communication of the expected or intended future path of the policy rate. Following the convention established by Campbell et al. (2012), researchers distinguish between Delphic and Odyssean guidance. The former is about the policy maker informing the public about the state of the economy and its evolution with no promise about future policy moves. In contrast, Odyssean guidance implies a pre-commitment to some (possibly state-contingent) set of future policy actions. ${ }^{5}$ Bernanke (2017) calls for the use of Odyssean guidance in the presence of (or near to) the ZLB in order to affect asset prices and the economy despite not being able to lower the policy rate. It is also desirable for central banks' to ensure that their Odyssean announcements are credible and, therefore, effective. ${ }^{6}$

Turning to quantitative easing, which is the purchase by central banks of securities in the open market financed with the creation of bank reserves held at the central bank, Bernanke (2017) points to two ways these operations can affect the economy. The first channel works through the 'signal' sent by the central bank that it intends to keep interest rates low for 
longer. This will influence agents' expectations. The second channel is the portfolio balance channel, which works because assets are not perfect substitutes. Thus variations in the supply of any particular asset change prices and yields, inducing investors to rebalance their portfolios.

\subsubsection{Increasing the Inflation Target}

In the presence of a lower real natural interest rate, the usually adopted 2 per cent inflation target would likely imply nominal interest rates hitting close to zero more frequently than in the past. This increased likelihood of hitting the ZLB would also imply worse outcomes than in the absence of such expectation according to research in Basu and Bundick (2015) and Seneca (2016). One proposal to lower the likelihood of falling into a liquidity trap is to increase the inflation target from 2 to 4 per cent (Blanchard, Dell'Ariccia and Mauro 2010).

The idea is that a 4 per cent inflation rate, while representing an affordable change in the cost of living, will give central banks much more room to manoeuvre. However, this change in the inflation target could have undesirable consequences, such as more volatile inflation due to, for instance, unanchored inflation expectations. ${ }^{7}$ Bernanke (2017) also discusses the pros and cons of raising the inflation target. He points out that the expected benefits are that it would be easy to implement and communicate as it would not be a dramatic departure from existing practice. The drawbacks are more challenging. First, re-anchoring inflation expectations at a different level could prove to be a long and uncertain process, as the Japanese case has taught us. Second, if expectations were to remain at a level below 4 per cent, for some time, the Federal Reserve would have to overheat the economy for an extended period to raise expectations up to the target. Overheating may turn out to be beneficial (say, to overcome hysteresis), but it might also lead to unstable inflation expectations. Increasing inflation would probably also be unpopular (because of a wrong perception by the public of the true cost of living because it is difficult to capture the true costs of inflation).

The issue about an appropriate inflation target is still an active area of research. Coibion and Gorodnichenko (2012) find that the US great moderation could have been due not only to a tighter monetary policy, but also to a lower inflation target pursued by the Federal Reserve. Arias et al. (2017) find that this result is less evident when using a richer business cycle model featuring productive capital, variable capital utilisation and wage stickiness. However, Coibion Gorodnichenko and Wieland (2012) find that, in a new-Keynesian framework, the optimal inflation target level is actually below 2 per cent.

Price-Level Targeting. Svensson (1999) first discussed the pros and cons of targeting the price level. Effectively, under a price-level targeting monetary policy regime, a central bank aims to keep the long-run average inflation rate to target while the inflation targeting 
central bank aims to keep inflation to target in the short run. Thus if inflation falls below the target for one period but reverts back to target for the following period, under inflation targeting, policy-makers would do nothing once inflation is back on target. In contrast, under price-level targeting, a central bank would try to reverse temporary deviations of inflation from target by engineering a policy move to counter the deviation in the opposite direction. Hence, periods of low inflation would be followed by periods of high inflation (and vice versa). This characteristic, which relates to history-dependence, renders price-level targeting appealing. In fact, some recent research suggests that price-level targeting could deliver a better outcome than inflation targeting (for a review, see Williams 2017). However, one drawback of this proposal with respect to monetary policy is the presence of supply shocks, which are inflationary and recessionary at the same time. In this case, while being theoretically optimal, monetary policy under price-level targeting would call for a tightening, which would (temporarily) exacerbate the economic downturn due to the shock.

\subsubsection{Temporary Price-Level Targeting}

Bernanke (2017) proposes a novel monetary policy framework based on the compromise between inflation targeting at 2 per cent, to be implemented in normal times, and pricelevel targeting, which the Federal Reserve should switch to when the ZLB is binding or close. Thus a necessary condition for raising the funds rate, from zero, will be when average inflation is at least 2 per cent. Beyond this necessary condition, the Committee will consider the outlook for the labour market and whether the return of inflation to target appears sustainable.

Figure 5 Cumulative PCE Inflation (Annualised) since 2008Q4

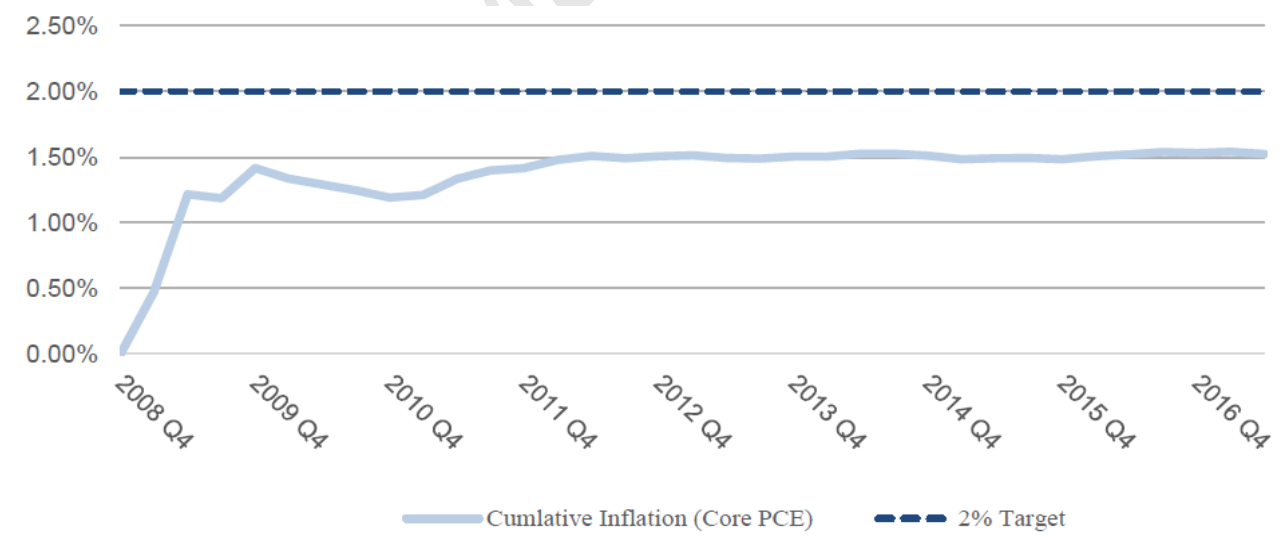

Source: Bernanke (2017).

Figure 5 plots the evolution of cumulative inflation since 2008Q4-the beginning of the ZLB period in the United States. Interestingly, Bernanke's (2017) temporary price-level targeting proposal would have possibly implied a delayed lift-off of the interest rate in the United 
States. Of course, this is purely hypothetical, in that if Bernanke's (2017) policy regime had been in place, agents' expectations over future policy realisations would likely be different, and therefore economic outcomes would likely be different too. For instance, lower longerterm yields might have resulted, and monetary policy effectiveness might have been greater. Hence, average inflation might have been higher and, therefore, the necessary condition for raising the policy rate would have been satisfied. Once again, it is important to stress that this is a purely speculative scenario.

\subsubsection{Shadow Rate Rule}

Bernanke (2017) formally discusses the link between his proposal and the shadow rate rule approach recently investigated by Kiley and Roberts (2017), which is to be used to determine the timing of the interest rate lift-off in the presence of the ZLB. The evolution of the unobserved shadow interest rate (Krippner 2012; Wu and Xia 2016) would depend on economic outcomes. For new-Keynesian models modelling Taylor rules of this sort, see Mouabbi and Sahuc (2017) and Wu and Zhang (2017). The assumption behind the 'shadow rate rule' is that such an unobserved rate would be understood and anticipated by the market. A major advantage of Bernanke's proposal is that it relies on an observable, which is the cumulative inflation rate during the ZLB period.

\subsubsection{Nominal GDP Targeting}

Summers (2016) proposes a switch from inflation targeting to nominal GDP targeting, say a growth rate of nominal GDP equal to, say, 4 to 5 per cent. This target would be a target for the sum of the growth rate of real GDP and inflation. Summers (2016) argues that a nominal GDP targeting would be preferable to, say, raising the inflation target for two reasons. First, it would guarantee a lower interest rate in response to a weakening of the economic system, something that a pure inflation targeting system would not imply. Second, nominal GDP targeting would not call for a timely measurement of inflation. Third, in the presence of adverse supply shocks, it would not necessarily imply a policy tightening that might just exacerbate the drop in GDP.

To put this proposal in context, it is a fact that the recovery in a number of economies, including the United States, has been slower than expected. This is in spite of the conventional and unconventional policy interventions engineered by the Federal Reserve (and the US Treasury). Would NGDP have delivered a better outcome? Advocates of NGDP targeting like Summers answer positively to this question because they point to the higher aggressiveness by the Federal Reserve in the presence of NGDP. The growth rate of nominal GDP was equal to 3.36 per cent during the period 2008Q4-2017Q3. Under a 4 or 5 per cent target, the Federal Reserve would have had to implement an even more accommodative policy, appealing more heavily to unconventional policy tools and, possibly, delaying the lift- 
off of the policy rate (which occurred in December 2016). Possibly, this more aggressive behaviour would have led to a faster and stronger recovery. That said, it is unclear how financial markets would react to switching to such a different policy framework.

\subsection{Fiscal Policy}

Fiscal policy was used as a stabilisation tool during the first phase of the Global Financial Crisis, in part due to unconventional monetary policy being stuck at the ZLB. However, in a number of countries-particularly those in the Euro Area-interventionist fiscal policy was tempered by fears of debt sustainability, so fiscal austerity replaced deficit-inducing fiscal policy. In part, this happened because fiscal spending multipliers were thought to be relatively low. This is one of the reasons why the literature on fiscal multipliers has reflourished since the advent of the GFC.

Some authors argue that fiscal consolidation should be through a reduction in fiscal spending as an increase in taxes could induce more harmful effects (Alesina, Favero and Giavazzi 2015; Alesina et al. 2015). Other authors find that fiscal spending multipliers can have a powerful effect on the business cycle (Blanchard and Leigh 2013), in particular during recessions (Auerbach and Gorodnichenko 2012; Caggiano et al. 2015); for different evidence, see Ramey and Zubairy (2017). Christiano, Eichenbaum and Rebelo (2011) consider fiscal spending at the ZLB and find fiscal policy shocks have powerful effects on the business cycle when the nominal interest rate is fixed and there is no crowding out of productive investment. Auerbach and Gorodnichenko (2017) work with OECD data and show that debt-GDP ratios fall in response to fiscal expansions when economies are in a recession and especially so when the debt-GDP ratio is initially low. To some extent, the ZLB creates an opportunity for expansionary fiscal policy because returns could be quite high.

As pointed out by Blanchard and Summers (2017), low interest rates can support an aggressive fiscal policy. If the real natural interest rate is lower than the growth rate of potential output, the economy could experience 'dynamic inefficiency', that is, an accumulation of capital financed by excess savings, which would eventually fall to facilitate consumption and boost aggregate demand. Hence, more public spending (which could eventually lead to private spending) would be desirable from society's point of view.

But even if the economy was dynamically efficient (which is, even if the growth rate of output exceeded the rate of interest), high levels of public debt may not be an issue, as the debt would be sustainable; enough resources would be generated to pay the debt service and eventually to fully settle the debt. Alternatively, since debt would be seen to be fully sustainable, an equilibrium condition could be that debt is never fully repaid. In a certain world, the debt/GDP ratio would never explode. However, in an uncertain world, 
characterised by future possible draws from the right tail of the distribution of the real natural interest rate and from the left tail of that of GDP growth, rational agents who are risk-averse might prefer holding liquidity to buying debt with uncertain repayment. The risk would call for the issuance of long-term debt indexed to, say, output growth rate (on the optimal mix and duration of public debt, see Missale and Blanchard 1994). This reasoning calls for more investigations on the design of optimal public debt. ${ }^{8}$

Another reason why a low interest rate environment could be favourable for fiscal policy interventions would be the low cost of government borrowing. A reduction in the burden of debt service is sufficient reason to undertake government investment and/or delay fiscal consolidation. However, Auerbach (2017) points out a few reasons for being cautious about this argument. First, countries experiencing population ageing face large implicit liabilities if pension funds and health care commitments are unfunded or underfunded. Given that such commitments represent future deficits, low interest rates actually raise their present value, resulting in a negligible fall in the current primary surplus. Second, if government spending crowds out private investment or increases the future cost of debt service, the current low rate of returns on government debt may not fully reflect its opportunity cost. Third, if debt is issued to publicly fund investment goods, irreversibility has to be taken into account in the presence of uncertainty about the future economic environment (Bloom 2009). As Auerbach puts it, there is no secondary market for bridges and highways. Auerbach (2017) elaborates further on these and related points.

\subsection{Monetary-Fiscal Policy Mix}

While we have discussed monetary and fiscal policies separately for ease of exposition, several contributions in the literature have forcefully stressed the interconnections between the two (see Leeper 1991 for an early reference; and Leeper and Leith 2016 for a recent survey). These interconnections relate, for example, to the impact on debt service exerted by policy moves, the effect on the nominal debt burden caused by changes in inflation, the inflationary pressures related to fiscal policy shocks affecting the business cycle, the adjustments in the inflation rate to satisfy the intertemporal budget constraint of the government, and so on. When acknowledging these interconnections, engineering high levels of public debt can turn out to be a costly choice.

Eusepi and Preston (2017a) propose a theory of the fiscal foundations of inflation based on imperfect knowledge and learning and show that the Great Moderation in the United States would not have been great if the public debt-over-GDP ratio had been characterised by the same level and composition observed in a number of European countries since the advent of the GFC. Their reasoning is as follows. Typically, rational expectation-DSGE models of inflation assign a dominant role to monetary policy and confine fiscal policy to the 
background. In the language of Leeper (1991), fiscal policy is 'passive'; that is, it just determines the value of debt while monetary policy is active (that is it is aggressively used to control inflation). Hence, these models point to a switch from bad to good monetary policy when it comes to explaining the dramatic reduction of macroeconomic volatilities (inflation, output growth) experienced by the United States since the mid-1980s and before the GFC.

What Eusepi and Preston (2017a) show is that this result falls apart when imperfect knowledge and learning are introduced. Imperfect knowledge makes agents uncertain about current and future policy regimes and therefore the long-term equilibrium levels of inflation and taxes. Agents will then try to learn these equilibrium levels by estimating econometric models to learn about them. Interestingly, Eusepi and Preston find that stability-defined as the set of policies that ensures agents correctly learn the long-run objectives of policy-is threatened when debt is elevated and of moderate maturity (between 2 and 7 years), which is indeed the maturity for most European countries. This is a crucial policy message because most European countries (with the notable exception of the United Kingdom) feature high debt levels and average debt maturities falling within this range. Eusepi and Preston show that, with a monetary policy as aggressive as the one estimated by Clarida, Gali and Gertler (2000) and debt levels and maturities comparable to the European ones, the US Great Moderation would have hardly occurred. As an aside, learning is a factor that would force researchers to re-evaluate the stabilising power of monetary policy even in models in which fiscal policy is secondary (Eusepi and Preston 2017b).

Bianchi and Melosi (2017) discuss yet another channel where monetary and fiscal policy interact. Using a microfounded regime-switching DSGE framework, which models different monetary-fiscal policy combinations à la Leeper (1991), they study the missing deflation in the United States during the ZLB period. They find that the uncertainty surrounding debt stabilisation could be the factor behind the missing deflation during the great recession. In particular, rational agents could have expected a passive monetary/active fiscal policy mix to be in place after the liftoff of the policy rate. Passive monetary policy would have allowed inflation and real activity to adjust to stabilise debt, therefore accommodating active fiscal policy. This combination of expected future policies would have therefore sustained inflation during and after the 2007-2009 recession in spite of the dramatic drop in real activity recorded in 2009. Eusepi and Preston's (2017a) and Bianchi and Melosi's (2017) contributions are examples of papers that warn against thinking of monetary and fiscal policies separately.

\subsection{Heterogeneous Agents}

One of the exciting developments in macroeconomic policy research is the recognition of how heterogeneity plays a crucial role in the effectiveness of policies. The effective 
transmission of policy changes is through their effects on asset prices and, eventually, on households' and firms' decisions. Recent contributions in the literature focusing on models with heterogeneous agents provide more sophisticated predictions regarding the power of policy announcements. McKay and Reis (2016) build a model with heterogeneous consumers who face idiosyncratic shocks and possibly binding borrowing constraints. They show that risk averse agents who anticipate the possibility of future binding borrowing constraints are less responsive to future interest rate changes than they would in the absence of such constraints.

Related to this, there are also studies that investigate how monetary policy shocks work through different transmission channels in the representative versus heterogeneous agents model. To make this point, Christiano, Eichenbaum and Trabandt (2017) focus on the Euler equation for consumption. In representative agent models, household's intertemporal consumption Euler equation is satisfied as a strict equality in all dates and states of nature. Hence, the representative household never faces borrowing constraints.

However, empirical evidence based on microdata typically rejects this assumption. Kaplan, Moll and Violante (2017) work with a heterogenous agents model in which just a small share of consumers satisfies the intertemporal Euler equation with equality. In such a model, a policy induced decrease in the interest rate has real effects working via two channels. The first channel is the direct effect of monetary policy, namely unconstrained agents increase their consumption following a cut to the policy rate. This in turn increases the income of the borrowing constraint and they increase their spending. This is the second channel-the indirect effect of monetary policy. Kaplan, Moll and Violante (2017) show that the indirect effects dominate the direct one. In this class of models, forward guidance is much less powerful (Kaplan, Moll and Violante 2016, 2017). Hence, these models may represent a solution to the forward guidance puzzle, that is, the excessively powerful role attributed to policy announcements in standard representative agents DSGE models (Del Negro, Giannoni and Patterson 2015).

\section{Conclusions}

This paper has reviewed the main explanations provided by the literature on the decline in the real natural interest rate in the United States and many other countries. It has also discussed the consequences of the current low interest rate environment for the design of monetary and fiscal policies. Following Blanchard and Summers (2017), a tentative conclusion is: yes, we are back to a view of the world that supports active (even aggressive) monetary and fiscal policies to stabilise the business cycle. The Keynesian view of policy is back in vogue! We conclude by listing a few research avenues that seem to be extremely relevant from a policy standpoint. 
First, identifying the main drivers of the low real natural interest rate is key for optimal policy design. To date, no dominant explanation has emerged. This is a problem for optimal policy design. For instance, stimulating consumption in order to free up resources now allocated to savings would require a different set of policy interventions (for example, reduction on direct taxes on consumption) from those policy-makers would engineer to stimulate investment (for example, incentives to hire workers, which would increase the marginal return to productive capital). Having a clear understanding of the main driver(s) of the current levels of interest rates would certainly represent a step forward for researchers and policy-makers aiming to design optimal policies.

Second, a consequence of the above mentioned uncertainty surrounding the drivers of the low real natural interest rate is that no simple reference forecasting model can be used to predict if and when real natural rates will return to higher levels any time soon. Hence, a natural question is: how to design policies in the presence of uncertainty surrounding future realisations of the real natural interest rate? And, empirically, does such uncertainty matter? These questions should be tackled by considering different transmission mechanisms, and possibly by considering not only representative agent models but also, in light of what has been discussed in this paper, heterogeneous agents frameworks or models in which agents do not have access to full information about the economy.

Third, hysteresis seems to be a hypothesis one should not discard a priori. While the natural rate hypothesis is the 'null hypothesis' central banks should keep considering (Blanchard 2017), consequences of monetary and fiscal policy implemented in a context in which cyclical movements have long-run implications are research material of great interest to policy-makers.

Our final word is that we might be back to Keynes, but the challenges faced by monetary and fiscal authorities today are of a different order. If the GFC has taught us anything, it is that economies are more tightly integrated by trade and financial linkages and that financial adjustments and spillovers are asymmetric and faster than before. Designing optimal policies in this complex context is tricky. We are certainly looking forward to reading future research aimed at designing optimal monetary and fiscal policies.

December 2017 


\section{References}

Aastveit, K. A., Natvik, G. J. and Sola, S. 2017, 'Economic uncertainty and the influence of monetary policy', Journal of International Money and Finance, vol. 76, pp. 50-67.

Alesina, A., Barbiero, O., Favero, C., Giavazzi, F. and Paradisi, M. 2015, 'Austerity in 2009-2013', Economic Policy, vol. 30, pp. 383-437.

Alesina, A., Favero, C. and Giavazzi, F. 2015, 'The output effect of fiscal consolidation plans', Journal of International Economics, vol. 96, pp. S19-42.

Alfaro, I., Bloom, N. and Lin, X. 2016, 'The finance-uncertainty multiplier', unpublished paper, Economics Department, Stanford University, viewed October 2016, $<$ https://people.stanford.edu/nbloom/research>.

Arias, E. J., Ascari, G., Branzoli, N. and Castelnuovo, E. 2017, 'Positive trend inflation and determinacy in a medium-sized new-Keynesian model', Federal Reserve Bank of Philadelphia Working Paper no. 17-16, Philadelphia.

Ascari, G. 2004, 'Staggered prices and trend inflation: Some nuisances', Review of Economic Dynamics, vol. 7, pp. 642-67.

Ascari, G. and Ropele, T. 2009, 'Trend inflation, Taylor Principle, and indeterminacy', Journal of Money, Credit and Banking, vol. 41, pp. 1,557-84.

Auerbach, A. J. 2017, 'Fiscal policy', Peterson Institute for International Economics, Washington, DC.

Auerbach, A. J. and Gorodnichenko, Y. 2012, 'Measuring the output responses to fiscal policy', American Economic Journal: Economic Policy, vol. 4, pp. 1-27.

Auerbach, A. J. and Gorodnichenko, Y. 2017, 'Fiscal stimulus and fiscal sustainability', National Bureau of Economic Research Working Paper no. 23789, Cambridge, Massachusetts.

Baker, S. R., Davis, S. J. and Bloom, N. 2016, 'Measuring economic policy uncertainty', Quarterly Journal of Economics, vol. 131, pp. 1,593-636.

Basu, S. and Bundick, B. 2015, 'Endogenous volatility at the zero lower bound: Implications for stabilization policy', National Bureau of Economic Research Working Paper no. 21838, Cambridge, Massachusetts.

Basu, S. and Bundick, B. 2017, 'Uncertainty shocks in a model of effective demand', Econometrica, vol. 85, pp. 937-58.

Bernanke, B. 2005, 'The global saving glut and the U.S. current account deficit', viewed December 2017, <https://www.federalreserve.gov/boarddocs/speeches/2005/200503102/>.

Bernanke, B. 2017, 'Monetary policy in a new era', Peterson Institute for International Economics, Washington, DC.

Bi, H. 2012, 'Sovereign risk premia, fiscal limits and fiscal policy,' European Economic Review, vol. 56, pp. 389-410.

Bianchi, F. and Melosi, L. 2017, 'Escaping the great recession', American Economic Review, vol. 107, pp. 1,030-58.

Blanchard, O. J. 2017, 'Should we get rid of the natural rate hypothesis?', Journal of Economic Perspectives, forthcoming.

Blanchard, O. J. and Leigh, D. 2013, 'Growth forecast errors and fiscal multipliers', American Economic Review, vol. 103, no. 3, pp. 117-20. 
Blanchard, O. J. and Summers, L. H. 2017, 'Rethinking stabilization policy. Back to the future', Peterson Institute for International Economics, Washington, DC.

Blanchard, O. J., Dell'Ariccia, G. and Mauro, P. 2010, 'Rethinking macroeconomic policy', Journal of Money, Credit and Banking, vol. 42, supp., pp. 199-215.

Blanchard, O. J., Dell'Ariccia, G. and Mauro, P. 2013, 'Rethinking macroeconomic policy II: Getting granular', International Monetary Fund Staff Discussion Note SDN/13/03.

Bloom, N. 2009, 'The impact of uncertainty shocks', Econometrica, vol. 77, pp. 623-85.

Bloom, N. 2014, 'Fluctuations in uncertainty', Journal of Economic Perspectives, vol. 28, no. 2, pp. 153-76.

Bloom, N., Floetotto, M., Jaimovich, N., Saporta, I. and Terry, S. 2016, Really uncertain business cycles, Stanford University, mimeo.

Bloom, N. 2017, 'Observations on uncertainty', Australian Economic Review, vol. 50, 79-84.

Caggiano, G. and Castelnuovo, E. 2017, 'Global uncertainty', unpublished paper, University of Melbourne, viewed December 2017, <https://sites.google.com/site/efremcastelnuovo/home>.

Caggiano, G., Castelnuovo, E. and Figueres, J. M. 2017a, 'Economic policy uncertainty spillovers', Melbourne Institute Working Paper No. 13/17..

Caggiano, G., Castelnuovo, E. and Figueres, J. M. 2017b, 'Economic policy uncertainty and unemployment in the United States: A nonlinear approach', Economics Letters, vol. 151, pp. 314.

Caggiano, G., Castelnuovo, E. and Groshenny, N. 2014, 'Uncertainty shocks and unemployment dynamics in U.S. recessions', Journal of Monetary Economics, vol. 67, pp. 78-92.

Caggiano, G., Castelnuovo, E. and Nodari, G. 2017, 'Uncertainty and monetary policy in good and bad times', Reserve Bank of Australia Research Discussion Paper no. 2017-06, Sydney.

Caggiano, G., Castelnuovo, E. and Pellegrino, G. 2017, 'Estimating the real effects of uncertainty shocks at the zero lower bound', European Economic Review, vol. 100, pp. 257-72.

Caggiano, G., Castelnuovo, E., Colombo, V. and Nodari, G. 2015, 'Estimating fiscal multipliers: News from a nonlinear world', Economic Journal, vol. 125, pp. 746-76.

Caggiano, G., Castelnuovo, E., Delrio, S. and Robinson, T. 2017, 'Time-dependent finance-uncertainty multipliers', Melbourne Institute of Applied Economic and Social Research, University of Melbourne, viewed December 2017, <https://sites.google.com/site/efremcastelnuovo/home>.

Caldara, D., Fuentes Albero, C., Gilchrist, S. and Zakrajšek, E. 2016, 'The macroeconomic impact of financial and uncertainty shocks', European Economic Review, vol. 88, pp. 185-207.

Campbell, J. R., Evans, C. L., Fisher, J. D. M. and Justiniano, A. 2012, 'Macroeconomic effects of FOMC forward guidance', Brookings Papers on Economic Activity, vol. 43, no. 1, pp. 1-80.

Carriero, A., Clark, T. E. and Marcellino, M. 2017, 'Assessing international commonality in macroeconomic uncertainty and its effects', unpublished paper, Federal Reserve Bank of Cleveland.

Carvalho, C., Ferrero, A. and Nechio, F. 2016 'Demographics and real interest rates: Inspecting the mechanism', European Economic Review, vol. 88, pp. 208-26.

Castelnuovo, E. and Pellegrino, G. 2017, 'Uncertainty-dependent effects of monetary policy shocks: A new Keynesian interpretation', Journal of Economic Dynamics and Control, forthcoming. 
Castelnuovo, E. and Tran, T. D. 2017, 'Google it up! A Google trends-based uncertainty index for the United States and Australia', Economics Letters, vol. 161, pp. 149-53.

Castelnuovo, E., Lim, G. and Pellegrino, G. 2017, 'A short review of the recent literature on uncertainty', Australian Economic Review, vol. 50, pp. 68-78.

Castelnuovo, E., Lim, G. and Robinson, T. 2016, Introduction to the Policy Forum: Macroeconomic consequences of macroprudential policies, Australian Economic Review, vol. 49, 77-82.

Christiano, L. J., Eichenbaum, M. S. and Rebelo, S. 2011, 'When Is the government spending multiplier large?', Journal of Political Economy, vol. 119, pp. 78-121.

Christiano, L. J., Eichenbaum, M. S. and Trabandt, M. 2017, 'On DSGE models', unpublished paper, Northwestern University.

Christiano, L. J., Motto, R. and Rostagno, M. 2014, 'Risk shocks', American Economic Review, vol. 104, pp. 27-65.

Clarida, R., Gali, J. and Gertler, M. 2000, 'Monetary policy rules and macroeconomic stability: Evidence and some theory', Quarterly Journal of Economics, vol. 115, pp. 147-80.

Coibion, O. and Gorodnichenko, Y. 2012 'The optimal inflation rate in New Keynesian models', Review of Economic Studies, vol. 79, pp. 1,371-406.

Colombo, V. 2013, 'Economic policy uncertainty in the US: Does it matter for the Euro area?', Economics Letters, vol. 121, pp. 39-42.

Dahlhaus, T. and Sekhposyan, T. 2017, 'Asymmetries in monetary policy uncertainty: New evidence from financial forecasts', unpublished paper, Bank of Canada and Texas A\&M University.

Davis, S. J. 2016, 'An index of global economic policy uncertainty', National Bureau of Economic Research Working Paper no. 22740, Cambridge, Massachusetts.

Del Negro, M., Giannone, D., Giannoni, M. and Tambalotti, A. 2017, 'Safety, liquidity, and the natural rate of interest', Brookings Papers on Economic Activity, vol. 48, pp. 235-94.

Del Negro, M., Giannoni, M. and Patterson, C. 2015, 'The forward guidance puzzle', Federal Reserve of New York Staff Report no. 574, New York.

Eggertsson, G. B. and Woodford, M. 2003, 'The zero bound on interest rates and optimal monetary policy', Brookings Papers on Economic Activity, vol. 34, pp. 139-221.

Eichengreen, B. 2015, 'Secular stagnation: The long view', American Economic Review, vol. 105, pp. 66-70.

Eickmeier, S., Metiu, N. and Prieto, E. 2016, 'Time-varying volatility, financial intermediation and monetary policy', Deutsche Bundesbank Discussion Paper no. 46, Frankfurt.

Eusepi, S. and Preston, B. 2017a, 'Fiscal foundations of inflation: Imperfect knowledge', unpublished paper, University of Melbourne.

Eusepi, S. and Preston, B. 2017b, 'The science of monetary policy: An imperfect knowledge perspective', Journal of Economic Literature, forthcoming.

Fernández-Villaverde, J., Guerrón-Quintana, P., Kuester, K. and Rubio-Ramírez, J. F. 2015, 'Fiscal volatility shocks and economic activity', American Economic Review, vol. 105, pp. 3,352-84.

Fries, S., Mesonnier, J., Mouabbi, S. and Renne, J.-P. 2017, 'National natural rates of interest and the single monetary policy in the Euro area', Banque de France Working Paper no. 611, Paris. 
Furman, J. 2017, 'Should policymakers care whether inequality is helpful or harmful for growth?', Peterson Institute for International Economics, Washington, DC.

Gagnon, E., Johannsen, B. K. and López-Salido, D. 2016, 'Understanding the new normal: The role of demographics', Finance and Economics Discussion Series no. 2016-080, Board of Governors of the Federal Reserve System, Washington.

Ghosh, A., Kim, J. I., Mendoza, E. G., Ostry, J. D. and Qureshi, M. S. 2013, 'Fiscal fatigue, fiscal space and debt sustainability in advanced economies', Economic Journal, vol. 123, pp. F4-30.

Gilchrist, S., Sim, J. W. and Zakrajšek, E. 2014, 'Uncertainty, financial frictions, and investment dynamics', National Bureau of Economic Research Working Paper no. 20038, Cambridge, Massachusetts.

Gordon, R. J. 2012, 'Is U.S. economic growth over? Faltering innovation confronts the six headwinds', National Bureau of Economic Research Working Paper no. 18315, Cambridge, Massachusetts.

Gourio, F., Siemer, M. and Verdelhan, A. 2013, 'International risk cycles', Journal of International Economics, vol. 89, pp. 471-84.

Hamilton, J. D., Harris, E. S., Hatzius, J. and West, K. D. 2016, 'The equilibrium real funds rate: Past, present, and future', IMF Economic Review, vol. 64, pp. 660-707.

Holston, K., Laubach, T. and Williams, J. C. 2017, 'Measuring the natural rate of interest: International trends and determinants', Journal of International Economics, vol. 108, pp. S5975.

Istrefi, K. and Mouabbi, S. 2017, 'Subjective interest rate uncertainty and the macroeconomy: A cross-country analysis', Journal of International Money and Finance, forthcoming.

Jurado, K., Ludvigson, S. and Ng, S. 2015, 'Measuring uncertainty', American Economic Review, vol. 105, pp. 1,177-216.

Kang, W., Ratti, R. A. and Vespignani, J. 2016, 'Global uncertainty and the global economy: Decomposing the impact of uncertainty shocks', Centre for Applied Macroeconomic Analysis Working Paper no. 39/2016 , Canberra.

Kaplan, G., Moll, B. and Violante, G. 2016, 'A note on unconventional monetary policy in HANK', unpublished paper, University of Chicago.

Kaplan, G., Moll, B. and Violante, G. 2017, 'Monetary policy according to HANK', American Economic Review, forthcoming.

Kiley, M. T. and Roberts, J. M. 2017, 'Monetary policy in a low interest rate world', Brookings Papers on Economic Activity, forthcoming.Krippner, L. 2012, 'Measuring the stance of monetary policy in zero lower bound environments', Economics Letters, vol. 118, pp. 135-8.

Krugman, P. R. 1998, 'It's Baaack: Japan's slump and the return of the liquidity trap', Brookings Papers on Economic Activity, vol. 29, no. 2, pp. 137-205.

Kulish, M., Morley, J. and Robinson, T. 2017, 'Estimating DSGE models with zero interest rate policy', Journal of Monetary Economics, vol. 88, pp. 35-49.

Laubach, T. and Williams, J. C. 2016, 'Measuring the natural rate of interest redux', Business Economics, vol. 51, no. 2, pp. 57-67.

Leeper, E. M. 1991, 'Equilibria under "active" and "passive" monetary and fiscal policies', Journal of Monetary Economics, vol. 27, pp. 129-47. 
Leeper, E. M. and Leith, C. 2016, 'Understanding Inflation as a joint monetary-fiscal phenomenon', in Handbook of Macroeconomics, vol. 2, eds J. B. Taylor and H. Uhlig, Elsevier, Oxford.

Lim, G. C., Chua, C. L., Claus, E. and Tsiaplias, S. 2009, 'Review of the Australian economy 2008/09: Recessions, retrenchments and risks', Australian Economic Review, vol. 42, pp. 1-11.

Liu, P., Haroon Mumtaz, H., Theodoridis, K. and Zanetti, F. 2017, 'Changing macroeconomic dynamics at the zero lower bound', Journal of Business \& Economic Statistics, forthcoming.

Ludvigson, S., Mah, S. and Ng, S. 2017, 'Uncertainty and business cycles: Exogenous impulse or endogenous response?', unpublished paper, New York University, viewed December 2017, $<$ http://www.sydneyludvigson.com/>.

Mauro, P., Romeu, R., Binder, A. and Zaman, A. 2015, 'A modern history of fiscal prudence and profligacy', Journal of Monetary Economics, vol. 76, pp. 55-70.

McCririck, R. and Rees, D. 2017, 'The neutral interest rate', Reserve Bank of Australia Bulletin, September, pp. 9-18.

McKay, A. and Reis, R. 2016, 'The role of automatic stabilizers in the U.S. business cycle', Econometrica, vol. 84, pp. 141-94.

Mendoza, E. G. and Ostry, J. D. 2008, 'International evidence on fiscal solvency: Is fiscal policy "responsible"?', Journal of Monetary Economics, vol. 55, pp. 1,081-93.

Miranda-Agrippino, S. and Rey, H. 2015, 'World asset markets and the global financial cycle', National Bureau of Economic Research Working Paper no. 21722, Cambridge, Massachusetts.

Missale, A. and Blanchard, O. J. 1994, 'The debt burden and debt maturity', The American Economic Review, vol. 84, 309-319.

Moore, A. 2016, 'Measuring economic uncertainty and its effects', Reserve Bank of Australia Research Discussion Paper no. 2016-01, Sydney.

Mouabbi, S. and Sahuc, J.-G. 2017, Evaluating the macroeconomic effects of the ECB's unconventional monetary policies, Banque de France, mimeo

Mumtaz, H. and Theodoridis, K. 2017, 'Common and country specific economic uncertainty', Journal of International Economics, vol. 105, pp. 205-16.

Nodari, G. 2014, 'Financial regulation policy uncertainty and credit spreads in the U.S.', Journal of Macroeconomics, vol. 41, pp. 122-32.

Pellegrino, G. 2017, 'Uncertainty and monetary policy in the US: A journey into non-linear territory', Melbourne Institute of Applied Economic and Social Research Working Paper no. 6/17, University of Melbourne.

Pellegrino, G. 2018, 'Uncertainty and the real effects of monetary policy shocks in the Euro area', Economics Letters, vol. 162, 177-181.

Rachel, L. and Smith, T. D. 2017, 'Are low real interest rates here to stay?', International Journal of Central Banking, vol. 13, no. 3, pp. 1-42.

Ramey, V. and Zubairy, S. 2017, 'Government spending multipliers in good times and in bad: Evidence from U.S. historical data', Journal of Political Economy, forthcoming.

Reserve Bank of Australia 2017, 'Minutes of the Monetary Policy Meeting of the Reserve Bank Board, 4 July 2017', Sydney. 
Ricco, G., Callegari, G. and Cimadomo, J. 2016, 'Signals from the government: Policy disagreement and the transmission of fiscal shocks', Journal of Monetary Economics, vol. 82, pp. 107-18.

Seneca, M. 2016, 'Risk shocks close to the zero lower bound', Bank of England Staff Working Paper no. 606 , London.

Summers, L. H. 2014, 'U.S. economic prospects: Secular stagnation, hysteresis, and the zero lower bound', Business Economics, vol. 49, no. 2, pp. 65-73.

Summers, L. H. 2016, 'A thought provoking essay from Fed President Williams', viewed December 2017, <http://larrysummers.com/2016/08/18/6937/>.

Svensson, L. E. O. 1999, Price-level targeting versus inflation targeting: A free lunch?, Journal of Money, Credit and Banking, vol. 31, 277-95

Wicksell, K. 1898, Interest and Prices: A Study of the Causes Regulating the Value of Money, trans. R. F. Kahn 1936, Macmillan, London.

Williams, J. C. 2017, 'Interest rates and the "new normal"', viewed December 2017, <http://www.frbsf.org/our-district/files/Williams-Speech-Interest-Rates-and-New-Normal.pdf>.

Wu, J. C. and Xia, F. D. 2016, Measuring the macroeconomic impact of monetary policy at the zero lower bound, Journal of Money, Credit, and Banking, vol. 48, 253-291.

Wu, J. C. and Zhang, J. 2017, 'A shadow rate new Keynesian model', Chicago Booth Research Paper no. 16-18, Chicago.

Yellen, J. 2016, 'The Federal Reserve's monetary policy toolkit: Past, present, and future', viewed December 2017, <https://www.federalreserve.gov/newsevents/speech/yellen20160826a.htm>.

\section{Endnotes}

1. While we have focused our discussion on monetary and fiscal policies when the natural rate is low, two other topics were also raised at the Meeting and they deserve special mention. For discussions on macroprudential policies, see Blanchard, Dell'Ariccia and Mauro (2013), Castelnuovo, Lim and Robinson (2016) and Blanchard and Summers (2017) and for a recent paper on the issue of inequality and macroeconomic policies, see for example, Furman (2017).

2. The workshop program is available at $<$ http://melbourneinstitute.unimelb.edu.au/eventsfolder/conferences/2017-macroeconomic-policy-meetings>.

3. Caldara et al. (2016) use a VAR framework and a non-recursive identification scheme to separately identify first (financial) and second moment (uncertainty) shocks. Caggiano et al. (2017) build on Caldara et al. and using a measure of financial uncertainty produced by Ludvigson, Mah and Ng (2017), they estimate a time-varying parameter VAR to quantify the evolution of the finance-uncertainty multiplier and their result is in line with the predictions of DSGE frameworks like Christiano, Motto and Rostagno (2014), Alfaro et al. (2016), Gilchrist, Sim and Zakrajšek (2014) on the role of financial frictions as multipliers of uncertainty shocks.

4. See among others, Fernández-Villaverde et al. (2015), Caggiano, Groshenny and Castelnuovo (2014), Nodari (2014), Basu and Bundick (2017), Caggiano, Castelnuovo and Pellegrino (2017), Kulish, Morley and Robinson (2017), and Liu et al. (2017). 
5. Research in Krugman (1998) and Eggetsson and Woodford (2003) suggest that a central bank facing the ZLB should promise to follow a history-dependent policy, that is, if policy today is tight because of the ZLB, the central bank should promise to keep the interest rate low for longer than otherwise. If the public understands this as a credible promise, then expectations of an easing policy and rapid growth in the future should work in favour of mitigating the recession and deflation during the ZLB period.

6. The term refers to Odysseus (also known as Ulysses), who tied himself to the mast in order to resist the temptation to go to the beautiful but deadly Sirens while on his journey back to Ithaca after the Trojan war.

7. The issue is more complicated than an increase in volatility as realisations of inflation on the right tail of the distribution could trigger sunspot fluctuations due to a loss of credibility by the central bank. Another issue pertains to the presence of price stickiness and price dispersion. According to models with this feature, a positive trend inflation rate requires a more aggressive systematic response by a central bank for sunspot fluctuations not to occur (Ascari 2004; Ascari and Ropele 2009).

8. A related recent literature is concerned with the definition and quantification of the 'fiscal limit', which is defined as the point where the government no longer has the ability to finance higher debt levels by increasing taxes, so either an adjustment to fiscal spending or monetary policy must occur to stabilise the debt. See, among others, the contributions by Mendoza and Ostry (2008), Bi (2012), Ghosh et al. (2013 and Mauro et al. (2015). 


\section{University Library}

\section{- M M I N E R VA A gateway to Melbourne's research publications}

Minerva Access is the Institutional Repository of The University of Melbourne

Author/s:

Castelnuovo, E;Lim, G;Pellegrino, G

Title:

Macroeconomic Policies in a Low Interest Rate Environment: Back to Keynes?

Date:

2018-03-01

Citation:

Castelnuovo, E., Lim, G. \& Pellegrino, G. (2018). Macroeconomic Policies in a Low Interest Rate Environment: Back to Keynes?. AUSTRALIAN ECONOMIC REVIEW, 51 (1), pp.70-86. https://doi.org/10.1111/1467-8462.12258.

Persistent Link:

http://hdl.handle.net/11343/283675 